\title{
Low-voltage Ride-through Methods for Grid-connected Photovoltaic Systems in Microgrids: A Review and Future Prospect
}

\author{
Haval Sardar Kamil ${ }^{1}$, Dalila Mat Said ${ }^{2}$, Mohd Wazir Mustafa ${ }^{3}$, Mohammad Reza Miveh ${ }^{4}$, Nasarudin \\ Ahmad $^{5}$ \\ ${ }^{1,2}$ Centre of Electrical Energy Systems (CEES), Universiti Teknologi Malaysia (UTM), Johor Bahru, Johor, Malaysia \\ ${ }^{1,2,3,5}$ School of Electrical Engineering, Universiti Teknologi Malaysia (UTM), Johor Bahru, Johor, Malaysia \\ ${ }^{4}$ Departement of Electrical Engineering, Tafresh University, Tafresh, Iran
}

\begin{tabular}{l} 
Article Info \\
Article history: \\
Received Jul 26, 2018 \\
Revised Aug 26, 2018 \\
Accepted Sep 9, 2018 \\
\hline Keyword: \\
Control strategy \\
Grid-feeding power converter \\
Low-voltage ride-through \\
Photovoltaic (PV) inverter
\end{tabular}

Corresponding Author:

Dalila Mat Said, Centre of Electrical Energy Systems (CEES), School of Electrical Engineering, Universiti Teknologi Malaysia (UTM), Johor Bahru 81310, Johor, Malaysia.

Email: dalila@utm.my

\begin{abstract}
Power quality is a concern for utility and grid operators due to a large penetration of intermittent and stochastic renewable power generation sources. One of the major concerns, when designing and controlling gridfeeding photovoltaic (PV) inverters is meeting the grid requirements. International grid requirements demand low-voltage ride-through (LVRT) capability and maintaining grid functionality during fault conditions. This paper presents a comprehensive review for several control techniques to assure the LVRT capability of grid-feeding converters as well as discussing their respective advantages and limitations in detail. Areas for further research are identified afterwards. Finally, the conclusion gives a brief summary and critique of the findings.
\end{abstract}

Copyright (ㅇ 2018 Institute of Advanced Engineering and Science. All rights reserved.

\section{INTRODUCTION}

The global warming problem together with the environmental issues has already pushed the governments to replace the conventional power plants with the renewable power generators with less emission[1-4]. Among various renewable power sources, photovoltaic (PV) systems have been commercialized in many countries for their industrial and environmental insight and their staggering grid integration through the controllable converters to reach the sustainable development. PV systems normally connected to the utility grid or microgrids using power electronic inverters to convert DC output power to AC output power.

Based on conventional control methods, PV systems should be disconnected from microgrids during grid faults conditions, due to the converter stability and protection. However, in recent years, a well-known requirement has set for PV systems called low-voltage ride-through (LVRT) capability, which is been applicable for other distributed generations regarding regenerative loads, compensation systems and energy storage applications [5]. In other words, the PV systems must be able to stay in connected to the microgrid for power quality enhancement under grid faults and to enhance voltage profile. The unregulated output power of PV power station under abnormal conditions can be regulated through grid-friendly converters, and the power system reliability can be guaranteed depending on the performance of these power converters.

Over the years, numerous LVRT control techniques have been proposed and introduced related to renewable energy technologies, which is obvious from increasing growth of relevant papers that have been 
published in assorted journals and proceedings [6-13]. So that, it seems convenient at this juncture to provide a comprehensive and cutting-edge review on existing LVRT control approaches of grid-feeding PV converter in microgrids due to the initial steps in grid code applications for PV systems. This paper mainly outlines a critical step that specifically deal with the latest research on LVRT methods which has been grown deeply, to follow it effectively, it is envisaged that some background knowledge would be helpful for certain group of readers. The remainder of this paper is structured as follows. Section 2 general control scheme for the gridfeeding converter. Section 3 presents existing LVRT control approaches for grid-feeding PV inverters. Discussion and future trends are given in Section 4. Finally, the conclusion is made in the last section.

\section{GENERAL CONTROL STRUCTURE OF THREE-PHASE GRID-FEEDING POWER CONVERTER}

The general control structure for a three-phase grid-feeding converter is described in Figure 1. It contains three main elements, including grid synchronization, inner loop control and outer loop control. It has been exposed that the main superiority of grid-feeding power converter is involved being consistently connected to the microgrid and avoiding islanding operation process.

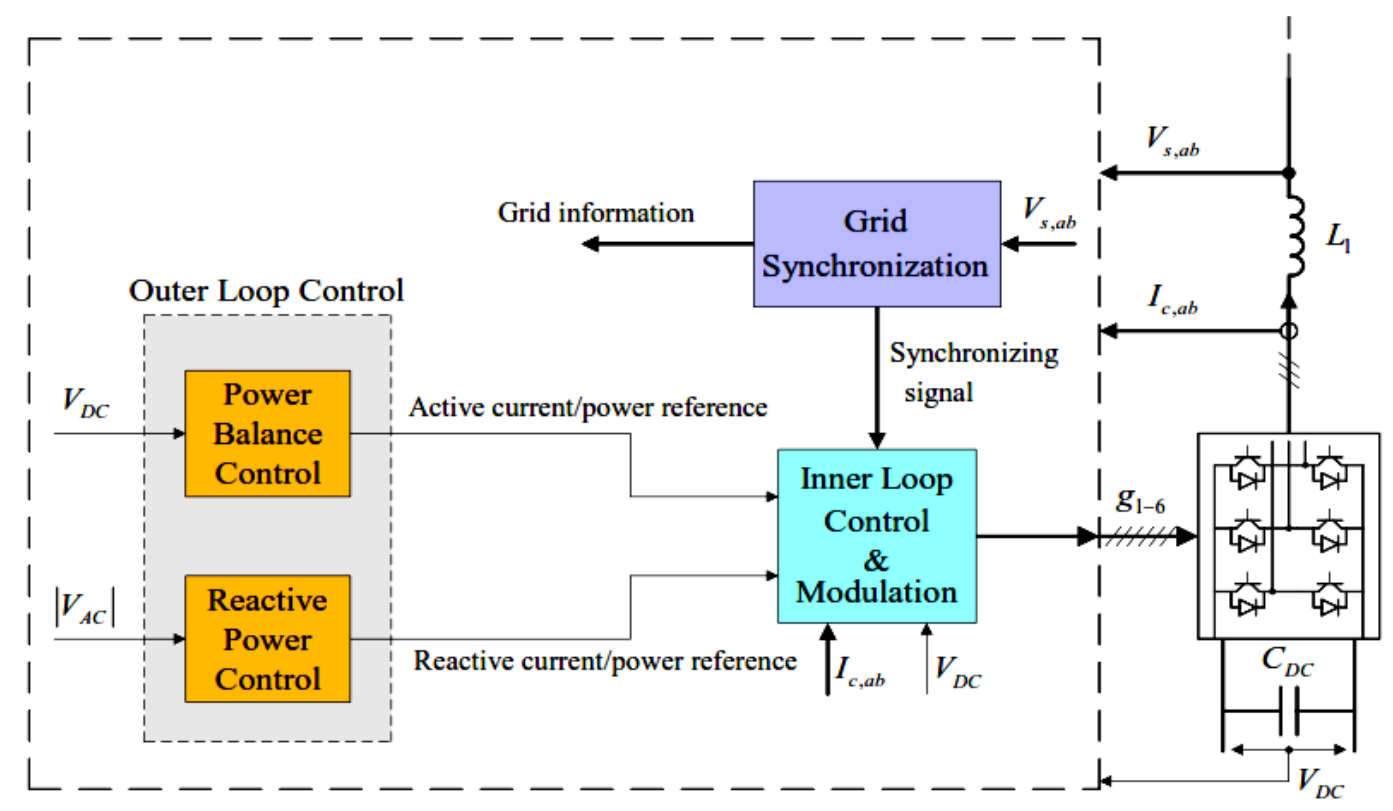

Figure 1. General control structure for a three-phase grid-feeding converter

For controlling active and reactive powers flow, certain information regarding voltage phase angle, amplitude and frequency is precisely required for the microgrid control system. However, identifying information is the main objective of the grid synchronization method which required by the rest of the control system. Despite a vast frame work range that have been proposed for synchronization strategies, the synchronous reference frame phased locked loop (SRF-PLL) is extremely most well-known synchronization method to be obtained [14].

Regarding the operation at the time of unbalanced grid voltage occurrence, normally identifying phase angle and amplitude of voltage's positive, negative and zero sequences are required for the synchronization method process in microgrid system. However, identifying phase angle and amplitude of different sequences at same instant of time is not yet being applied for grid-feeding power converters. Thus, adding functionality to conventional synchronization method, or to implement techniques for separating symmetrical components sequence under unbalanced conditions is a must. As the inner control loops are controlling the PWM switching functionality of the converter and regulating the outer loops performance limits accordingly, the inner loop controller is required to be fast and accurate[15]. Moreover, the inner loops controller can be further designed to be in control of both the active and reactive power flow precisely. 


\section{AVAILABLE LVRT CONTROL APPROACHES FOR GRID-FEEDING PV INVERTER UNDER UNBALANCED CONDITIONS}

A simple process for the unbalanced three-phase current control which is inseparable of measured currents into their individualized sequence components is proposed in [10]. The approach combines with a classical synchronous frame of proportional integral (PI) regulators with boosted gains, to accomplish stellar unbalanced three phase current control with a minimal complexity. Figure 2, illustrates the new scheme, where the combined synchronous reference frame targeting sequence current references are being produced by use of direct DC components, along with a twice frequency component from the adverse synchronous reference frame (SRF). Hence, either controller works to balance both the positive sequence as well as negative sequence currents at the instant time simultaneously, accordingly, these sequence currents would not be required for separate extraction from the feedback signal measurement. The method frequently decreases the current controller complexity, as the consequence, when the high potential gains of PI controller are used, considerably enhances the efficient response of the current regulation technique.

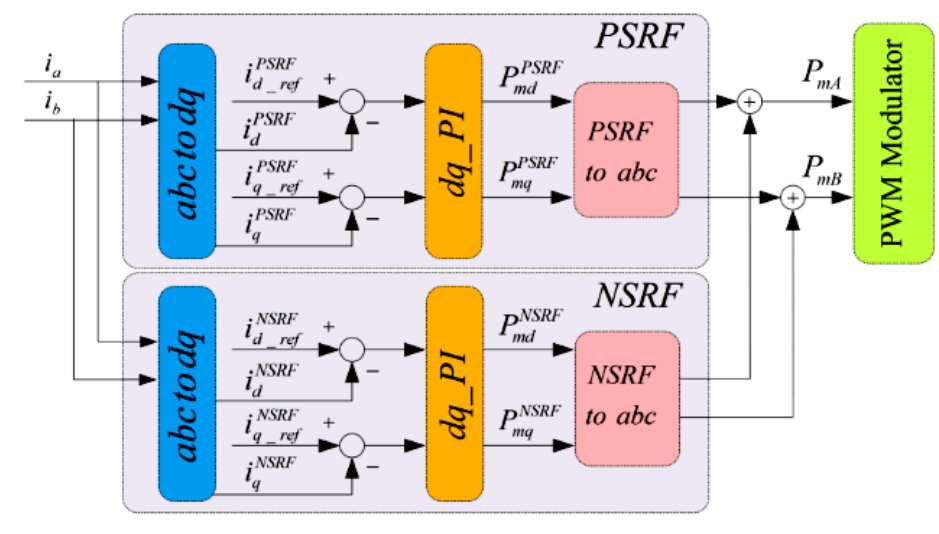

Figure 2. Proposed unbalanced DG current control strategy [10]

Castilla et al. [11], presented a fully control strategy destined for synchronous compensators which operate under abnormal faulty network situation. Particularly, the introduced control strategy proposes two specific contributions, as novel reference generator of the reactive current and unprecedented voltage support loop controller as well. Moreover, the reference generator of current has a main aspect capacity for supplying the desired reactive current even while the voltage drops in amplitude throughout sag voltage. Hence, a secure system operation is comfortably guaranteed by fixing the required limited current to the highest rated current. The voltage loop controller due to setting two set points of voltage can perform various control strategies. Furthermore, for this study three control schemes for voltage support have been carried out, regardless to their merits and limitations.

In [16], the control strategy of both positive sequence and negative sequence components of the large scale grid-connected PV system in critical unbalanced voltage sag situations in the network system is deliberated. Some problems concerning system's dynamic performance and stability occur while proportional integral controllers are applied in current loops controller. However, delay is the purpose that the filtering approach demands because of the voltage and current sequences extraction. Despite this delay, the system's dynamic response getting slower in respect to the situation when no filtration approach is required. Moreover, there is a robust constraint on selecting appropriate parameters for the voltage and current loop controllers without compromising circumstances of the stability of system.

The work by Du et al. [17], presenting the research study of instantaneous active and reactive power fluctuation for three-phase grid-connected voltage source converter. Hence, the quadrature characteristics of the fluctuated active and reactive power effects in the sine-term and cosine-term performances which are merely resolved by the average active and reactive power correspondingly. Moreover, by the reason of average active power and average reactive power decoupling effect to the oscillated power, the control strategy of positive and negative sequence conductance and susceptance (PNGB) is proposed to manage and control the grid fault events. The detailed correlations between control parameters of susceptance and conductance with the power fluctuation amplitude and peak phase current have been derived. Hence, a control approach to PNGB current has been introduced for regulating oscillated instantaneous active and 
reactive power. Furthermore, embedding current limitation strategy into the control loop for the sake of overcurrent prevention.

In [5], the photovoltaic inverter controller which assures minimum peak values in injected currents of the grid for the time of sag voltage is introduced. However, this method is established on the derived algorithm. Additionally, the design technique is progressed beneficial to explore for the values of control parameter where lessen the peak currents at the time of voltage sags of grid. A comprehensive mathematical investigation of currents is implemented during the voltage sag for developing the proposed control design. Regarding the evaluation of this control design performance, a detailed comparison obtained between currents with the presented control scheme and the other control approaches is expressed as well. As the encouraging aspect, reducing ripples in injected power at the time of sag occurrence is noticed, thereafter, decreasing ripples in DC-link voltage, which would be critical in some particular situations.

The generalized control scheme of active power for DG inverter operates under unbalanced grid disturbances is presented in [18]. On the basis of derived formulation and graphical illustration, the realized contributions of symmetrical sequence elements to the instantaneous power and interactions among symmetrical sequences is deeply elaborated. Due to proposing a flexible parameter between grid voltages and reference currents, an effective technique is constructed to control the dc-link ripples and the symmetric shape of the current or power factor concerning controllable fluctuated active and reactive powers. Consequently, from the prospect of power electronic converter and power system the technique analysis is being explained. In view of the flexible adaptivity of the proposed technique, it is permitted to collaborate with various restraints in experiential layout.

In [19], various approaches that concern with controlling the distributed generation systems is proposed in case of unbalanced situations that are brought on by faults in the utility network. Moreover, the analytical consequences permit for designing the flexible controller of active power that can adjust itself for faulty conditions and is more reconfigurable in terms of changing requirements of grid specially. In specific, it is being validated that, throughout unbalanced events, there is a possibility for obtaining zero active and reactive power oscillations only just by obtaining extremely high distorted currents. The work by Valouch et al. [20], expresses the grid current control strategy at the level of power converter. The proffered analysis takes charge of the control approach of positive and negative current sequences in the grid interconnected converter at time of voltage sag. Moreover, the control strategy must ensure appropriate interchange of active and reactive powers devoid of power ripple, harmonic distortion alleviation of grid currents, and should set up grid currents peaks control additionally. A pure expression is resolved, which permits estimation of highly exchangeable active and reactive powers between the converter and the grid without surpassing the allowable converter current.

Shao et al. [21], have presented a transformerless three-level photovoltaic power converter and the consequences of the unbalanced faults on the inverter's neutral point for LVRT operation are figured out. Moreover, new proposed control techniques are carried out to further balance the voltage oscillations on the neutral point of the inverter under unbalanced faults. In [22], Ma and his research group investigate a threephase system, which offers six current control freedoms with a zero-sequence current path to alleviate both active and reactive power fluctuations and inject sinusoidal currents as well. However, the constant dc source has been used, the drawbacks of the unbalanced faults on the capacitive dc-link have not been investigated. Cardenas et al. [23], assume that the dc-link voltage is to be constant. This assumption is inappropriate in terms of the unbalanced fault as overall power would not be zero and the ripple would be produced to the dclink voltage. Afshari et al.[24], propose a model for PV source at the input side system, the performance of the proposed technique is only evaluated through simulations. The proposed control strategy including two operational modes, MPPT and non-MPPT modes, which they may operate under unbalanced conditions. The authors of [25], illustrated the LVRT operation of current source grid-connected PV inverters under unbalanced voltages. Moreover, the proposed method developed negative sequence current reference to abolish active power double frequency fluctuations at the Ac side of the current source grid connected PV inverter. Guo et al.[26], propose a new fault ride through FRT control strategy for grid connected inverters. In the proposed method a pick current can control within the rated value effectually. A flexible control strategy for three-phase PV inverters operating under unbalanced faults is discussed, nevertheless, the control of the renewable energy source has not been explored.

\section{DISCUSSION AND FUTURE TRENDS}

The mentioned control strategies can be classified based on various consideration, as shown in Table 1. As shown in the table, the control scheme of three-phase grid feeding power converters can be designed in three different coordinate systems, which are the natural $a b c$ reference frame, the stationary $\alpha \beta o$ reference frame, and the $d q$ rotating frame. Various current controller techniques to the three-phase grid- 
connected converters in three-phase three-wire systems has been proposed. A comparison of all the studies about current control techniques is presented in Table 2. This comparative study listing the benefits and drawbacks of each controller.

Table 1. Different Control Strategies for Grid-feeding PV Inverter

\begin{tabular}{|c|c|c|c|c|c|c|}
\hline References & $\begin{array}{l}\text { Reference } \\
\text { frame }\end{array}$ & $\begin{array}{l}\text { Active-reactive } \\
\text { power control }\end{array}$ & $\begin{array}{c}\text { Reference } \\
\text { current } \\
\text { generator }\end{array}$ & $\begin{array}{l}\text { Inner current } \\
\text { control }\end{array}$ & $\begin{array}{l}\text { Synchronization } \\
\text { Method }\end{array}$ & Target \\
\hline $\begin{array}{c}\text { (Sosa et al., } \\
\text { 2016) }\end{array}$ & $\begin{array}{l}\text { Stationary } \\
\text { reference } \\
\text { frame }\end{array}$ & $\begin{array}{l}\text { Active/reactive } \\
\text { power injection }\end{array}$ & $\begin{array}{l}\text { Controllable } \\
\text { active power } \\
\text { oscillation }\end{array}$ & $\begin{array}{l}\text { Proportional- } \\
\text { Resonant (PR) }\end{array}$ & PLL & $\begin{array}{c}\text { Three-phase } \\
\text { three-wire system }\end{array}$ \\
\hline $\begin{array}{c}\text { (Chen et al., } \\
\text { 2016) }\end{array}$ & $\begin{array}{l}\text { Synchronous } \\
\text { reference } \\
\text { frame }\end{array}$ & $\begin{array}{l}\text { Active/reactive } \\
\text { power injection }\end{array}$ & $\begin{array}{l}\text { Controllable } \\
\text { active power } \\
\text { oscillation }\end{array}$ & $\begin{array}{l}\text { Proportional- } \\
\text { Integral (PI) }\end{array}$ & PLL & $\begin{array}{c}\text { Three-phase } \\
\text { three-wire system }\end{array}$ \\
\hline $\begin{array}{l}\text { (Rodríguez et } \\
\text { al., 2015) }\end{array}$ & $\begin{array}{l}\text { Stationary } \\
\text { reference } \\
\text { frame }\end{array}$ & $\begin{array}{l}\text { Active/reactive } \\
\text { power injection }\end{array}$ & Disconnection & PR & $\begin{array}{l}\text { DSOGI-FLL, } \\
\quad(\text { FLL) }\end{array}$ & $\begin{array}{c}\text { Three-phase } \\
\text { three-wire system }\end{array}$ \\
\hline $\begin{array}{l}\text { (Kou et al., } \\
\text { 2015) }\end{array}$ & abc frame & $\begin{array}{l}\text { Active/reactive } \\
\text { power injection }\end{array}$ & $\begin{array}{l}\text { Controllable } \\
\text { active power } \\
\text { oscillation }\end{array}$ & PI & - & $\begin{array}{l}\text { Three-phase } \\
\text { three-wire system }\end{array}$ \\
\hline $\begin{array}{l}\text { (Mirhosseini et } \\
\text { al., 2015) }\end{array}$ & $\begin{array}{l}\text { Synchronous } \\
\text { reference } \\
\text { frame }\end{array}$ & $\mathrm{P}=0, \mathrm{Q}=0$ & Disconnection & PI & $\begin{array}{l}\text { Moving average } \\
\text { filters (MAFs) }\end{array}$ & $\begin{array}{c}\text { Three-phase } \\
\text { three-wire system }\end{array}$ \\
\hline $\begin{array}{l}\text { (Kabiri et al., } \\
\text { 2015) }\end{array}$ & $\begin{array}{l}\text { Synchronous } \\
\text { reference } \\
\text { frame }\end{array}$ & $\mathrm{P}=0, \mathrm{Q}=0$ & Disconnection & PI & PLL & $\begin{array}{c}\text { Three-phase } \\
\text { three-wire system }\end{array}$ \\
\hline $\begin{array}{l}\text { (Castilla et al., } \\
\text { 2014) }\end{array}$ & $\begin{array}{l}\text { Stationary } \\
\text { reference } \\
\text { frame }\end{array}$ & $\begin{array}{l}\text { Positive/negative } \\
\text { sequence reactive } \\
\text { power injection }\end{array}$ & - & PI & PLL & $\begin{array}{c}\text { Three-phase } \\
\text { three-wire system }\end{array}$ \\
\hline $\begin{array}{l}\text { (Du et al., } \\
\text { 2016) }\end{array}$ & $\begin{array}{l}\text { Synchronous } \\
\text { reference } \\
\text { frame }\end{array}$ & $\begin{array}{l}\text { active/reactive } \\
\text { power injection }\end{array}$ & $\begin{array}{c}\text { Controllable } \\
\text { active/reactive } \\
\text { power } \\
\text { oscillation }\end{array}$ & $\begin{array}{c}\text { Conductance / } \\
\text { saucepans control } \\
\text { scheme }\end{array}$ & - & $\begin{array}{c}\text { Three-phase } \\
\text { three-wire system }\end{array}$ \\
\hline $\begin{array}{l}\text { (Miret et al., } \\
\text { 2012) }\end{array}$ & abc frame & $\begin{array}{l}\text { Positive/negative } \\
\text { sequence reactive } \\
\text { power injection }\end{array}$ & - & PI & PLL & $\begin{array}{c}\text { Three-phase } \\
\text { three-wire system }\end{array}$ \\
\hline $\begin{array}{c}\text { (Wang et al., } \\
\text { 2012) }\end{array}$ & $\begin{array}{l}\text { Stationary } \\
\text { reference } \\
\text { frame }\end{array}$ & $\begin{array}{l}\text { Positive sequence } \\
\text { active power } \\
\text { injection }\end{array}$ & - & PR & $\begin{array}{l}\text { Sequence } \\
\text { detection }\end{array}$ & $\begin{array}{c}\text { Three-phase } \\
\text { three-wire system }\end{array}$ \\
\hline $\begin{array}{l}\text { (Rodriguez et } \\
\text { al., 2007) }\end{array}$ & $\begin{array}{l}\text { Synchronous } \\
\text { reference } \\
\text { frame, } \\
\text { Stationary } \\
\text { reference } \\
\text { frame }\end{array}$ & $\begin{array}{l}\text { Positive/negative } \\
\text { sequence reactive } \\
\text { power injection }\end{array}$ & $\begin{array}{c}\text { Controllable } \\
\text { active/reactive } \\
\text { power } \\
\text { oscillation }\end{array}$ & PI, PR & $\begin{array}{l}\text { second-order } \\
\text { generalized } \\
\text { integrator } \\
\text { bandpass filter } \\
\text { (SOGI-BPF) }\end{array}$ & $\begin{array}{c}\text { Three-phase } \\
\text { three-wire system }\end{array}$ \\
\hline $\begin{array}{c}\text { (Valouch et al. } \\
\text { 2015) }\end{array}$ & $\begin{array}{l}\text { Synchronous } \\
\text { reference } \\
\text { frame }\end{array}$ & $\begin{array}{l}\text { Positive/negative } \\
\text { sequence reactive } \\
\text { power injection }\end{array}$ & $\begin{array}{c}\text { Controllable } \\
\text { active/reactive } \\
\text { power } \\
\text { oscillation }\end{array}$ & PI & PLL & $\begin{array}{c}\text { Three-phase } \\
\text { three-wire system }\end{array}$ \\
\hline
\end{tabular}

Table 2. Benefits and Limitations of Control Structures

\begin{tabular}{|c|c|c|c|}
\hline $\begin{array}{c}\text { Control } \\
\text { strategies }\end{array}$ & $\begin{array}{l}\text { Associated controller } \\
\text { type }\end{array}$ & Advantage & Disadvantage \\
\hline dq frame & PI & $\begin{array}{c}\text { Easy hardware implementation } \\
\text { Simple current control } \\
\text { Good dynamic response } \\
\text { Fixed switching frequency }\end{array}$ & $\begin{array}{l}\text { Very poor harmonics compensation } \\
\text { Steady-state error is not eliminated }\end{array}$ \\
\hline abc frame & PR & Fixed switching frequency & $\begin{array}{c}\text { Complex transfer function } \\
\text { Slow dynamic response } \\
\text { More complex with refer to hysteresis } \\
\text { and dead-beat } \\
\text { Slow dynamic response }\end{array}$ \\
\hline$\alpha \beta$ frame & $\mathrm{RC}$ & $\begin{array}{c}\text { High gain around resonance frequency } \\
\text { Steady-state error omitting is very good } \\
\text { High dynamic response } \\
\text { Good current harmonic compensation especially } \\
\text { low-order } \\
\text { High gain at the integral multiples of the } \\
\text { fundamental frequency } \\
\text { High order harmonics compensator }\end{array}$ & $\begin{array}{c}\text { Complex hardware implementation } \\
\text { Slow dynamic response with DC } \\
\text { signals }\end{array}$ \\
\hline
\end{tabular}


The active and reactive power control, reference current generator, current controller and the synchronization method for each strategy is presented in the last section as well. Regarding the literature, previous research in this specific field have only focused on the control of three-phase grid-feeding converters under unbalanced situations in three-wire systems. Nevertheless, far too little consideration has been paid to the control of such kind grid-connected inverters in three-phase four-wire systems. It is due to the reality that the positive, negative and zero sequence components should be organized and handled in three-phase four-wire systems simultaneously, which is resulting in a complex control algorithm.

The current control of the grid-feeding converters in three phase three-wire systems under unbalanced grid-fault conditions is a well-developed and mature research topic. Nonetheless, far too little attention has been paid to current control of the grid-feeding power converters in three-phase four-wire islanded microgrids due to presence of positive, negative as well as zero sequence components. On the basis of the previous studies, the current control techniques for grid-feeding power converters operating in the three-phase four-wire systems often suffering from slow transient response and complicated control algorithm. Therefore, it is important to propose an improved current control technique for three phase gridfeeding power converter operating in three-phase four-wire islanded microgrid for compensating positive, negative and zero sequence component with fast dynamic response and simple control structure. Furthermore, the phase angle and magnitude of positive, negative and zero sequence voltage components in four-wire network typically used for synchronization of grid-feeding converter output variables, calculation of power flow or transformation of stationery variable components into rotating reference frames. Hence, grid synchronization of grid-feeding power converters operating in the three-phase four-wire islanded microgrid is an essential.

\section{CONCLUSION}

In this paper, the recently published papers about LVRT control methods for grid-feeding PV inverters operating under unbalanced conditions in microgrids were assessed and investigated as a comprehensive review. Multi-purpose PV inverters have fascinated increasing concern for their contributions to ancillary services for the enhancement of power quality in the stand-alone and autonomous distribution systems. The presented LVRT control techniques classified based on various applications, including type of inverters, control schemes, and control adjustment. In order to improve power quality and stability in islanded microgrid different control schemes have conferred and compared in detail. This paper is expected to be a useful reference for researchers, engineers and manufacturers involved in PV systems.

\section{ACKNOWLEDGEMENTS}

The authors wish to acknowledge the Ministry of Education, Malaysia and Universiti Teknologi Malaysia for supporting this research under Grant QJ130000.2423.03G88.

\section{REFERENCES}

[1] L. Naik, "Design and Performance of a PV-STATCOM for Enhancement of Power Quality in Micro Grid Applications," International Journal of Power Electronics and Drive Systems (IJPEDS), vol. 8, no. 3, pp. 1408$1415,2017$.

[2] S. K. Bhuyan, P. K. Hota, and B. Panda, "Power Quality Analysis of a Grid-connected Solar/Wind/Hydrogen Energy Hybrid Generation System," International Journal of Power Electronics and Drive Systems (IJPEDS), vol. 9, no. 1, pp. 377-389, 2018.

[3] A. Naderipour, A. M. Zin, M. Habibuddin, M. Moradi, M. Miveh, and H. Afrouzi, "A new compensation control strategy for grid-connected wind turbine and fuel cell inverters in a microgrid," International Journal of Power Electronics and Drive Systems (IJPEDS), vol. 8, no. 1, pp. 272-278, 2017.

[4] H. S. Kamil, D. M. Said, M. W. Mustafa, M. R. Miveh, N. Rosmin, and N. Ahmad, "DIgSILENT modelling of a four-leg power converter using a triangular carrier wave," in Energy Conversion (CENCON), 2017 IEEE Conference on, 2017, pp. 343-348: IEEE.

[5] J. Miret, M. Castilla, A. Camacho, L. G. de Vicuña, and J. Matas, "Control scheme for photovoltaic three-phase inverters to minimize peak currents during unbalanced grid-voltage sags," IEEE transactions on Power Electronics, vol. 27, no. 10, pp. 4262-4271, 2012.

[6] H.-C. Chen, C.-T. Lee, P.-T. Cheng, R. Teodorescu, and F. Blaabjerg, "A low-voltage ride-through technique for grid-connected converters with reduced power transistors stress," IEEE Transactions on Power Electronics, vol. 31, no. 12 , pp. 8562-8571, 2016.

[7] N. Guerrero-Rodríguez, A. B. Rey-Boué, L. C. Herrero-de Lucas, and F. Martinez-Rodrigo, "Control and synchronization algorithms for a grid-connected photovoltaic system under harmonic distortions, frequency variations and unbalances," Renewable Energy, vol. 80, pp. 380-395, 2015. 
[8] W. Kou, D. Wei, P. Zhang, and W. Xiao, "A direct phase-coordinates approach to fault ride through of unbalanced faults in large-scale photovoltaic power systems," Electric Power Components and Systems, vol. 43, no. 8-10, pp. 902-913, 2015.

[9] M. Mirhosseini, J. Pou, and V. G. Agelidis, "Single-and two-stage inverter-based grid-connected photovoltaic power plants with ride-through capability under grid faults," IEEE Trans. Sustain. Energy, vol. 6, no. 3, pp. 1150$1159,2015$.

[10] R. Kabiri, D. Holmes, and B. McGrath, "Double synchronous frame current regulation of distributed generation systems under unbalanced voltage conditions without sequence current separation," in Applied Power Electronics Conference and Exposition (APEC), 2015 IEEE, 2015, pp. 1822-1829: IEEE.

[11] M. Castilla, J. Miret, A. Camacho, J. Matas, and L. G. de Vicuña, "Voltage support control strategies for static synchronous compensators under unbalanced voltage sags," IEEE transactions on industrial electronics, vol. 61, no. 2, pp. 808-820, 2014.

[12] M. R. Miveh, M. F. Rahmat, A. A. Ghadimi, and M. W. Mustafa, "Power quality improvement in autonomous microgrids using multi-functional voltage source inverters: a comprehensive review," Journal of Power Electronics, vol. 15, no. 4, pp. 1054-1065, 2015.

[13] J. L. Sosa, M. Castilla, J. Miret, J. Matas, and Y. Al-Turki, "Control strategy to maximize the power capability of PV three-phase inverters during voltage sags," IEEE Transactions on Power Electronics, vol. 31, no. 4, pp. 3314$3323,2016$.

[14] N. Jaalam, N. Rahim, A. Bakar, C. Tan, and A. M. Haidar, "A comprehensive review of synchronization methods for grid-connected converters of renewable energy source," Renewable and Sustainable Energy Reviews, vol. 59, pp. 1471-1481, 2016.

[15] T. L. Vandoorn, J. C. Vasquez, J. De Kooning, J. M. Guerrero, and L. Vandevelde, "Microgrids: Hierarchical control and an overview of the control and reserve management strategies," IEEE industrial electronics magazine, vol. 7 , no. 4, pp. 42-55, 2013.

[16] M. Mirhosseini, J. Pou, B. Karanayil, and V. G. Agelidis, "Positive-and negative-sequence control of gridconnected photovoltaic systems under unbalanced voltage conditions," in Power Engineering Conference (AUPEC), 2013 Australasian Universities, 2013, pp. 1-6: IEEE.

[17] X. Du, Y. Wu, S. Gu, H.-M. Tai, P. Sun, and Y. Ji, "Power oscillation analysis and control of three-phase gridconnected voltage source converters under unbalanced grid faults," IET Power Electronics, vol. 9, no. 11, pp. 2162 2173, 2016.

[18] F. Wang, J. Duarte, and M. Hendrix, "Design and analysis of active power control strategies for distributed generation inverters under unbalanced grid faults," IET generation, transmission \& distribution, vol. 4, no. 8, pp. 905-916, 2010.

[19] P. Rodriguez, A. V. Timbus, R. Teodorescu, M. Liserre, and F. Blaabjerg, "Flexible active power control of distributed power generation systems during grid faults," IEEE Transactions on Industrial Electronics, vol. 54, no. 5, pp. 2583-2592, 2007.

[20] V. Valouch, M. Bejvl, P. Šimek, and J. Škramlík, "Power control of grid-connected converters under unbalanced voltage conditions," IEEE Transactions on Industrial Electronics, vol. 62, no. 7, pp. 4241-4248, 2015.

[21] Z. Shao, X. Zhang, F. Wang, R. Cao, and H. Ni, "Analysis and control of neutral-point voltage for transformerless three-level PV inverter in LVRT operation," IEEE Transactions on Power Electronics, vol. 32, no. 3, pp. $2347-$ $2359,2017$.

[22] K. Ma, W. Chen, M. Liserre, and F. Blaabjerg, "Power controllability of a three-phase converter with an unbalanced AC source," IEEE Transactions on Power Electronics, vol. 30, no. 3, pp. 1591-1604, 2015.

[23] R. Cárdenas, M. Díaz, F. Rojas, J. Clare, and P. Wheeler, "Resonant control system for low-voltage ride-through in wind energy conversion systems," IET Power Electronics, vol. 9, no. 6, pp. 1297-1305, 2016.

[24] E. Afshari, B. Farhangi, Y. Yang, and S. Farhangi, "A low-voltage ride-through control strategy for three-phase grid-connected PV systems," in Power and Energy Conference at Illinois (PECI), 2017 IEEE, 2017, pp. 1-6: IEEE.

[25] Z. Wang, B. Wu, D. Xu, M. Cheng, and L. Xu, "Dc-link current ripple mitigation for current-source grid-connected converters under unbalanced grid conditions," IEEE Transactions on Industrial Electronics, vol. 63, no. 8, pp. 49674977, 2016.

[26] X. Guo, W. Liu, and Z. Lu, "Flexible power regulation and current-limited control of the grid-connected inverter under unbalanced grid voltage faults," IEEE Transactions on Industrial Electronics, vol. 64, no. 9, pp. 7425-7432, 2017. 


\section{BIOGRAPHIES OF AUTHORS}
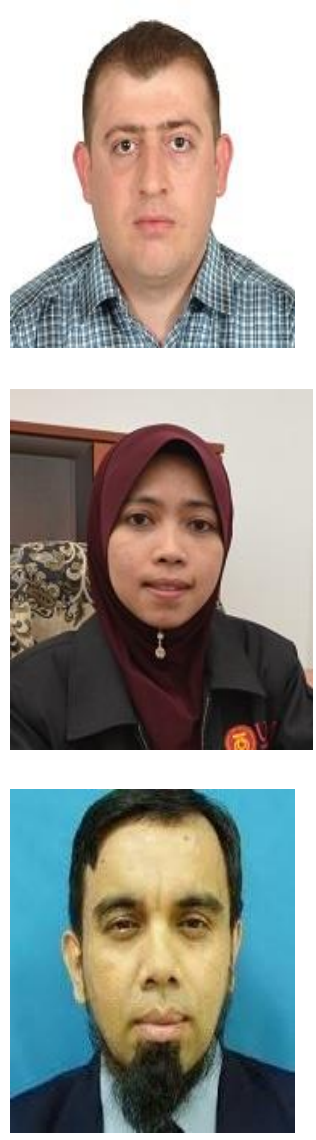

Mohd Wazir Mustafa received his B.S. Degree (1988), M. Sc. (1993) and PhD (1997) from University of Strathclyde. He is currently a Professor and Chair of School of Electrical Engineering, Universiti Teknologi Malaysia (UTM), Johor Bahru, Malaysia. His research interest includes power system stability, FACTS and power system distribution automation, deregulated power system, etc. He is a professional engineer of IEEE

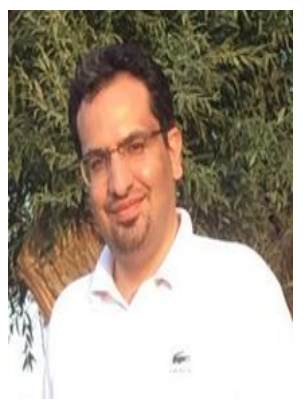

Mohammad Reza Miveh received his Ph.D. (Electrical Engineering) from Universiti Teknologi Malaysia (UTM) in 2017. Currently, he is Assistant Professor in Department of Electrical Engineering at Tafresh University, Tafresh, Iran. His research interests are in the area of microgrid, distributed generation, fuel cell and simulation and analysis of power system.

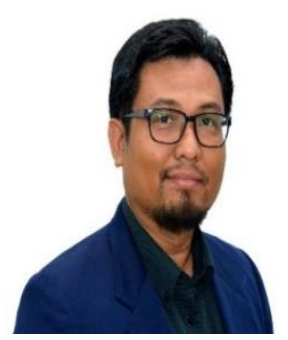

Nasarudin Ahmad received B. Sc and M. Sc degrees in electrical engineering from Universiti Teknologi Malaysia, in 1998 and 2000 respectively. Since 2000 he has been a lecturer in School of Electrical Engineering, Universiti Teknologi Malaysia. His interest in research activities are application of instrumentation technique in power system 